\title{
ARTÍCULOS
}

\section{POLICY LABS IN EUROPE: POLITICAL INNOVATION, STRUCTURE AND CONTENT ANALYSIS ON TWITTER}

\section{Policy labs en Europa: innovación política, estructura y análisis de contenido en Twitter}

Esteban Romero-Frías and Wenceslao Arroyo-Machado

Nota: Este artículo se puede leer en español en:

http://www.elprofesionaldelainformacion.com/contenidos/2018/nov/02_esp.pdf

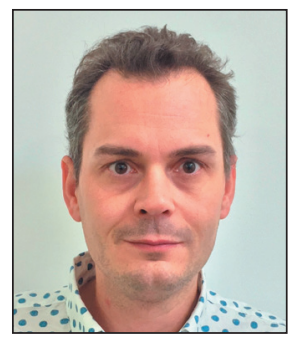

Esteban Romero-Frías is a tenured professor at the University of Granada (UGR) in the Department of Finance and Accounting. He is the director of Medialab UGR - Research Laboratory for Digital Culture and Society of the UGR. His research has focused mainly on the application of webmetric techniques to the field of business and politics, as well as the use of digital technologies in education. He is working on digital culture, digital scholarship and digital humanities and social sciences.

http://medialab.ugr.es

http://estebanromero.com

https://orcid.org/0000-0003-2205-3560

erf@ugr.es

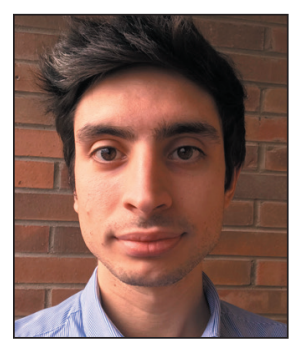

Wenceslao Arroyo-Machado holds a degree in Information and Documentation and a master's degree in Data Science and Computer Engineering (University of Granada). He has worked as a researcher in the project Knowmetrics - evaluation of knowledge in the digital society funded by the BBVA Foundation. His works focus on this and other areas derived related to the new paradigm of the digital humanities and data science.

https://orcid.org/0000-0001-9437-8757

wences@ugr.es

Universidad de Granada, Medialab UGR, CTT Gran Vía, 48. 18010 Granada, Spain

\begin{abstract}
Recent years have seen a veritable boom in the creation of policy labs. These institution-based innvation laboratories aim to open up the processes of public policy design to the social stakeholders involved. In 2016, the European Union Policy Lab commissioned a report that identified 64 such laboratories in Europe. In the present study, we use network analysis to reveal the structure of the relationships between the 42 of these labs that have a presence on Twitter. We then conduct a content analysis of their tweets to identify the topics of interest. Our results describe a fragmented, country-based network and the principal concepts and key issues addressed by these institutions.
\end{abstract}

\section{Keywords}

Twitter; Policy labs; Social networks; Text mining; Content analysis.

\section{Resumen}

En los últimos años ha proliferado la creación de policy labs, laboratorios institucionales de innovación que tienen por objetivo abrir los procesos de diseño de políticas públicas a los diversos actores sociales implicados. En 2016 el Policy Lab creado por la Unión Europea promovió un informe en el que se identificaban 64 laboratorios de este tipo en Europa. El presente trabajo emplea análisis de redes para desvelar la estructura de las relaciones entre los 42 labs con presencia en Twitter. Posteriormente efectúa un análisis de contenido de los tuits publicados con el fin de conocer las temáticas de interés. Los resultados muestran una red fragmentada por países, así como los conceptos y temas clave de estos organismos. 


\section{Palabras clave}

Twitter; Policy labs; Redes sociales; Minería de textos; Análisis de contenidos.

Romero-Frías, Esteban; Arroyo-Machado, Wenceslao (2018). "Policy labs in Europe: political innovation, structure and content analysis on Twitter". El profesional de la información, v. 27, n. 6, pp. 1181-1192.

\section{Introduction and literature review}

Social laboratories are initiatives designed to address social challenges. According to Romero-Frías and Robinson-García (2017), they are characterized by:

- their social nature, integrating differing human perspectives in collaborative work;

- an experimental approach, involving the application of innovation methods; and

- a systemic approach to the generation of scalable solutions that address global problems.

Their objective to transform and achieve social innovation (European Commission, 2014) give them an eminently political nature. In recent decades, the development of data-driven, digital, open innovation approaches (Chesbrough, 2003 ; 2006) that use co-creation to integrate society as a whole, has fully involved institutional agents when it is they that control the implementation of policies and actions in society.

One way in which this has been achieved is through institutions such as the Living Labs (Almirall; Wareham, 2008) which, according to the European Commission (2009), place the user at the center of the innovation process by coordinating with other stakeholders, integrating varied interests, and integrating multiple skills and abilities in decision making. This approach to innovation is based on the quadruple helix model (government, industry, academia and civil society) (Cavallini et al., 2016), in which multiple knowledge transfer processes give prominence to civil society.

In this context, in the last 10 years several public administrations have opted to incorporate these innovation initiatives into the system itself through the creation of policy labs or government laboratories (hereinafter, laboratories or labs). These laboratories place citizens at the center of their innovation processes, promoting more proactive institutions that seek to recover the political initiative and increase people's confidence in them. This movement finds an echo in the New public management (Barzelay, 2001) that began to develop in the 1980s, although it has been molded and shaped by current trends in open government (Lathrop; Ruma, 2010), digital participation and e-government (Dunleavy et al., 2016).

The European Commission has founded its own policy lab which, according to its website, is defined as a "collaborative and experimental space for innovative policy-making". https://blogs.ec.europa.eu/eupolicylab

It is described as both a physical space and a way of working that combines foresight, behavioral insights and design thinking in order to explore, connect and find solutions that develop better policies. In June 2016, the European Commission Joint Research Centre, on which the lab depends, published a report entitled "Public policy lab in European Union member states", prepared by Conseil \& Recherche and the 27e Région (France) (Fuller; Lochard, 2016). The aim of this report was to map the policy labs operating in the EU at that time and their principal topics of interest (p. 2).

The report characterized the policy labs to be included in the study as follows:

- "Policy labs approach policy issues through a creative, design, or user-oriented perspective.

- Policy labs strive to organize experiments to test proposed policies.

- Policy labs work for or within a government entity or public administration, and contribute to the shaping or implementation of public policies."

Apart from the EU lab, another significant case included in the report is the UK Policy Lab, located within the United Kingdom government's Cabinet Office - the department directly supporting the Prime Minister and Cabinet. https://openpolicy.blog.gov.uk/category/policy-lab

Its goal is to provide government departments at all levels with new techniques to generate public policies and design services that take account of people's experience, data analysis and new digital tools.

Policy labs place citizens at the center of their innovation processes, promoting more proactive institutions that seek to recover the political initiative and increase people's confidence in them

To sum up, policy labs are framed within an open government strategy in a digital society that employs innovation methods in a quadruple helix knowledge transfer approach.

From a political perspective, these labs can play an important role in promoting public agendas by both identifying issues that are important to citizens and by placing issues at the center of social debate (McCombs, 1996). Policy labs conduct political communication by using the digital tools characteristic of our times (Castells, 2013). By examining the expression of their digital identities on Twitter - one of the most open networks for research purposes and one that is also intensively used in politics- we hope to discover the relationships between these organizations and the characteristics of their communication on this network.

The use of Twitter as an indicator of a given activity's impact 
has been studied significantly in the evaluation of science through altmetrics (Priem; Hemminger, 2010; Torres-Salinas; Cabezas-Clavijo; Jiménez-Contreras, 2013). Research has focused on the nature of the network (Robinson-García et al., 2017), on generating university rankings as a function of research paper dissemination (Torres-Salinas et al., 2018), and on how universities communicate on social media (Zarco; Del-Barrio-García; Cordón, 2016). However, in addition to its use in the field of science, Twitter is an especially interesting network when measuring other types of audience (Wilsdon et al., 2015; Sugimoto et al., 2016) or social phenomena. This overflow from altmetrics into other topics had previously occurred in areas such as webometrics - a website-centered approach to digital information. Webometric studies have analyzed political phenomena such as the European election results (Romero-Frías; Vaughan, 2010) or the relationship between media and political parties in a given country (Romero-Frías; Vaughan, 2012).

Another framework relevant to the present study is network theory, which enables us to understand and model complex systems (Lewis, 2008). Different types of graph allow us to reflect real world behavior through individual participants (nodes), and the implicit or explicit relationships established between them (edges), which may exhibit some directionality. Twitter is one such complex system in which we can observe relationships such as the explicit connections of retweets and mentions (Del-Fresno-García, 2014). These connections can be analyzed from two general perspectives by focusing on:

- social relations between individuals through established follow-up connections (taking account of the double, bi-directional follower/friend perspective);

- the information network based on tweet-produced interaction (Myers et al., 2014).

The objective is to be able to describe and then study a given community's underlying network and to analyze this via a range of indicators and statistics. This approach has been used in the field of politics, for example:

- to determine the political orientation of the media (Golbeck; Hansen, 2011);

- in case studies of politicians' discourse on social media (Ceron, 2017);

- in the organization of dialog between political parties through Twitter (Martínez-Rolán; Piñeiro-Otero, 2017);

- in the relationships established by parliamentarians (Cherepnalkoski, 2016; Weaver et al., 2018);

- or as a basis for social laboratory case studies (Romero-Frías; Robinson-García, 2017).

The present literature review allows us to connect different areas of research in order to apply network theory to the analysis of the new forms of political innovation that policy labs represent in Europe. The present article focuses on the structure of the European network of policy labs on Twitter and, through content analysis, suggests what may be some of the key elements in this communication.

\section{Research questions}

The present study aims to answer the following questions about policy labs in Europe:
- What is the profile of those policy labs that have a presence on Twitter?

- What is the nature of the network of relations between European policy labs on Twitter?

- What is the content of policy lab publications (tweets)?

\section{Material and methods}

\subsection{Data collection on Policy Lab accounts}

The European Commission report entitled "Public Policy Labs in European Member States" identifies 64 laboratories in $13 \mathrm{EU}$ countries and maps their geolocations. It includes the European Commission's own policy lab and 13 others considered "influencers" - that is, EU-based institutions missing from the sample because they have no direct link to a government institution.

For each policy lab, a search of their profiles was done on Twitter through Google, the Twitter search engine itself and links on their own institutional websites. As of April 1, 42 laboratories of the 64 identified were found, including the European Commission's lab. Throughout this work Twitter users are employed in order to identify the entity in question when they are mentioned in the text.

In some cases, profile identification is difficult since the associated Twitter accounts may not be exclusively dedicated to the policy lab's activity. Labs with descriptions suggesting they are primarily or exclusively used by the policy lab have been included. Similarly, we have included labs with a wider scope if their profiles or tweet content refer to innovation activities covered by the abovementioned definition. Two such labs are @CityofOdense and @AlpesMaritimes. In some cases, we have found accounts have been redirected (for example: the @UKTIIdeasLab profile is now redirected to @TradeDesignLab - the latter is the one included in the present study). Another case is the UNHCR policy lab, linked globally to the United Nations but located in the report on a Refugee Aid Initiative in Greece (@UNHCRInnovation). This lab has been included in the network analysis study but omitted from the tweet content analysis because its worldwide profile means that its message transcends the European level.

Our content analysis of Twitter publications has shed light on the nature of this type of institution

Henceforth, our analysis and the results presented will be based exclusively on the reduced sample of 42 laboratories.

\subsection{Data processing}

The data gathered from Twitter (profiles and connections between them) were collected through scripts programmed in python using the Tweepy and Twython libraries. Descriptive statistics of mean, standard deviation (SD) and follower/friend ratios were calculated from the follower and friend data.

The policy lab network was analyzed by visualizing the connections between the 42 laboratories by using Gephi (Bastian; Heymann; Jacomy, 2009).

https://gephi.org 
The graph obtained has allowed us to analyze how the laboratories identified in the report are related to each other and to determine which network nodes are most relevant in order to obtain an overview. This analysis has been conducted on a global scale, considering the network as a whole, and at the local level, paying attention to each node or lab.

At a global level, the diameter, maximum eccentricity (greatest distance) between all node pairs, and the mean distance between all of them, have been calculated. For each node the degree of entry (indegree) and exit (outdegree) have been considered; these are equivalent to account followers and friends, respectively. Likewise, eigenvector centrality has been calculated (Bonacich, 2010). This is determined through an iterative process, which takes into account the degree of entry and exit of a node and the quality of these connections. We have weighted those accounts that are followed by others that are considered relevant.

To identify the labs' key communication issues, the tweet content published by each profile was analyzed. Data was extracted by downloading, as of April 24, 2018, the maximum number of tweets allowed for each account: a total of approximately 3,200 . Hence, in many cases, all the tweets from a given lab have been analyzed; failing that, we have analyzed a broad, recent sample of their tweets. A total of 73,375 tweets were downloaded, including own tweets $(44,083)$ and retweets from other accounts $(29,292)$ in any language. In order to simplify our analysis, we have only included each lab's own tweets published in English (21,391).

For our content analysis of tweets (see section 4.3), a text mining process has been carried out using the Knime software (version 3.5.3), in order to clean tweet texts by eliminating URLs, hashtags, mentions of other accounts, numerical values, special characters and punctuation marks.

\section{https://www.knime.com}

Next, a grammar tag was assigned to all terms with a minimum of three characters by using OpenNLP.

\section{http://opennlp.apache.org}

Empty words (pronouns, prepositions, conjunctions, etc.) were then eliminated and the terms were lemmatized using the Snowball library to reduce them to their root forms. http://snowball.tartarus.org

Finally, the relevant keywords have been extracted from the tweets of each account through a process based on the KeyGraph algorithm (Ohsawa; Benson; Yachida, 1998). Table 1 summarizes the methodology used in this process.

\section{Results}

\subsection{Description of policy labs and their profiles on Twitter}

Of the 42 laboratories with a presence on Twitter, only the EU Policy Lab is located at the European level. The remaining 41 laboratories are geographically distributed as follows: 14 in the United Kingdom, 8 in France, 5 in Denmark, 3 in Spain, 3 in the Netherlands, 2 each in Italy and Sweden, and only 1 each in Finland, Greece, Ireland and Portugal.

English is the language of reference used on Twitter accounts. In 20 labs, at least $50 \%$ of tweets are published in English (Table 3). In 15 labs, more than 90\% of tweets are in English. The other principal languages used are: French, with at least 8 labs; Danish and Dutch with 3 each; minority languages include Catalan, Finnish, Italian, and Spanish, among others.

\section{English is the language of reference used on Twitter accounts. In 20 labs, at least $50 \%$ of tweets are published in English}

The European Commission report identifies institutional linkage as follows: 10 labs belong to local institutions, 6 metropolitan, 5 regional, and 14 national; 7 are related to other institutions.

It also identifies various reference topics to which laboratories devote their efforts. From the most to the least frequent, these are:

- public sector innovation (19 labs);

- healthy and inclusive societies (15);

- jobs and growth (11);

- digital economy and society (10);

- local and regional economic development (8);

- transport and mobility (5);

- resource efficiency, circular economy and waste (4);

- culture and education (4);

- migration, integration and humanitarian aid (1);

- finance and taxes (1).

Quantitative data for the Twitter profiles, as of April 2, 2018, can be consulted in Annex 1. The 42 labs have:

- a mean 17,792.07 followers (SD: 49,139.71);

- a mean of friends' accounts of 971.9 (SD: 992.79);

- a mean of published tweets of 5871.97 (SD: 9111.34).

Table 1. Schema of the selection, capture and data treatment processes

\begin{tabular}{|c|l|l|l|}
\cline { 2 - 4 } \multicolumn{1}{c|}{} & \multicolumn{1}{c|}{ Action } & Tool & Result \\
\hline 1 & Data collection of policy lab profiles & Twitter & Identification of 42 of the 64 laboratories in the European Commission report \\
\hline 2 & Downloading data from the Twitter API & Python & \\
\hline 3 & Study of relationships between policy labs & Gephi & Internal network formed by 29 labs with 77 relationships \\
\hline 4 & Analysis of policy lab communication through tweets & Knime & Text mining based on 21,391 tweets in English \\
\hline
\end{tabular}


If we use lab profiles to obtain the number of followers as an indicator of presence on Twitter (Zarco; Del-Barrio-García; Cordón, 2016), the most relevant labs are:

- DFID_UK (293,843),

- gdsteam $(116,104)$,

- CreativeScots $(83,433)$,

- AlpesMaritimes $(48,881)$, and

- SitraFund $(31,740)$.

Note that, in last place, with fewer than 100 followers, we have the two Italian labs, CoMantova (63) and CoBattipaglia (36).

With respect to the follower/friend ratio, some laboratories receive a lot of attention in relation to the number of accounts they follow (DFID_UK, 133.44 times the number of friends; gdsteam, 98.56; AlpesMaritimes, 66.6), which may indicate their ability to influence on Twitter.

Finally, we should consider the number of tweets - that is, the number of publications a given account has made, including retweets, since its creation - as an indicator of lab activity: the five outstanding labs are:

- BarcelonaLab (49,939);

- DFID_UK (20,539);

- SitraFund (19,931);

- LBofBexley $(15,946)$;

- CreativeScots (15,642).

Again, the two Italian labs are the least prolific with fewer than 100 tweets each.

One important factor is the regularity of lab profile updates on Twitter: 35 of the 42 have tweeted within a year since the data collection date. Currently, some accounts appear to be inactive:

- DCCStudio (last tweet in 2015);

- CoMantova (2015);

- CoBattipaglia (2015);

- labo_demo (February 2017);

- TradeDesignLab (March 2017).

\subsection{Network analysis of rela- tions between European policy labs}

Figure 1 shows the network based on the follow-up relationships between the policy labs included in the sample; that is, the connections established between the nodes that are both indegree (follower) and outdegree (friend) and which are reflected by the directions of the arrows on the edges. A total of 29 connected labs are identified (13 nodes have no connection of any type and do not appear in the network). Furthermore, some 77 connections, or edges, are established between labs (the "degree", seen in Table 2). The mean number of connections between labs (the sum of indegree and outdegree) is 5.31; the standard deviation of followers (indegree) is 3.17 , and of friends (outdegree) 2.25. This indicates greater dispersion in the number of followers each lab receives by comparison with the number of laboratories followed. This could be explained by the greater concentration of followers in some policy labs (MindLabDK with 15 followers or PolicyLabUK with 9), while others are scarcely followed (in fact, Sitrafund, millenaire3, poleemploi_lab and LEFfuturecenter have no followers). The network diameter is 6, which indicates the maximum number of connections between the two most distant nodes. The mean distance between all nodes is 2.75 .

Node color in the network indicates the degree of eigenvector centrality, ranging from 0 (blue) to 1 (red). The size of each node is calculated from the indegree. The thickness of the edges has no specific meaning.

In Figure 1, two main clusters are identified by the number of nodes attached. In the upper part, we can see a set of 9 UK-based labs, among which PolicyLabUK occupies the central position. This lab defines itself as a creative space in which various UK government teams can design and test new ways of working. It is a policy lab created in 2014 within the UK government Cabinet Office, which implies that it is situated at a very high level in the administration. It is the node with the second highest eigenvector centrality in the figure (0.830), which explains the relevance of its position globally and, particularly, within British politics. Within the same cluster, iLab_NI, the public innovation laboratory of Northern Ireland, is ranked fourth by centrality (0.737). It was set up in 2014 in the government's Finance Department in order to innovate in developing public services.

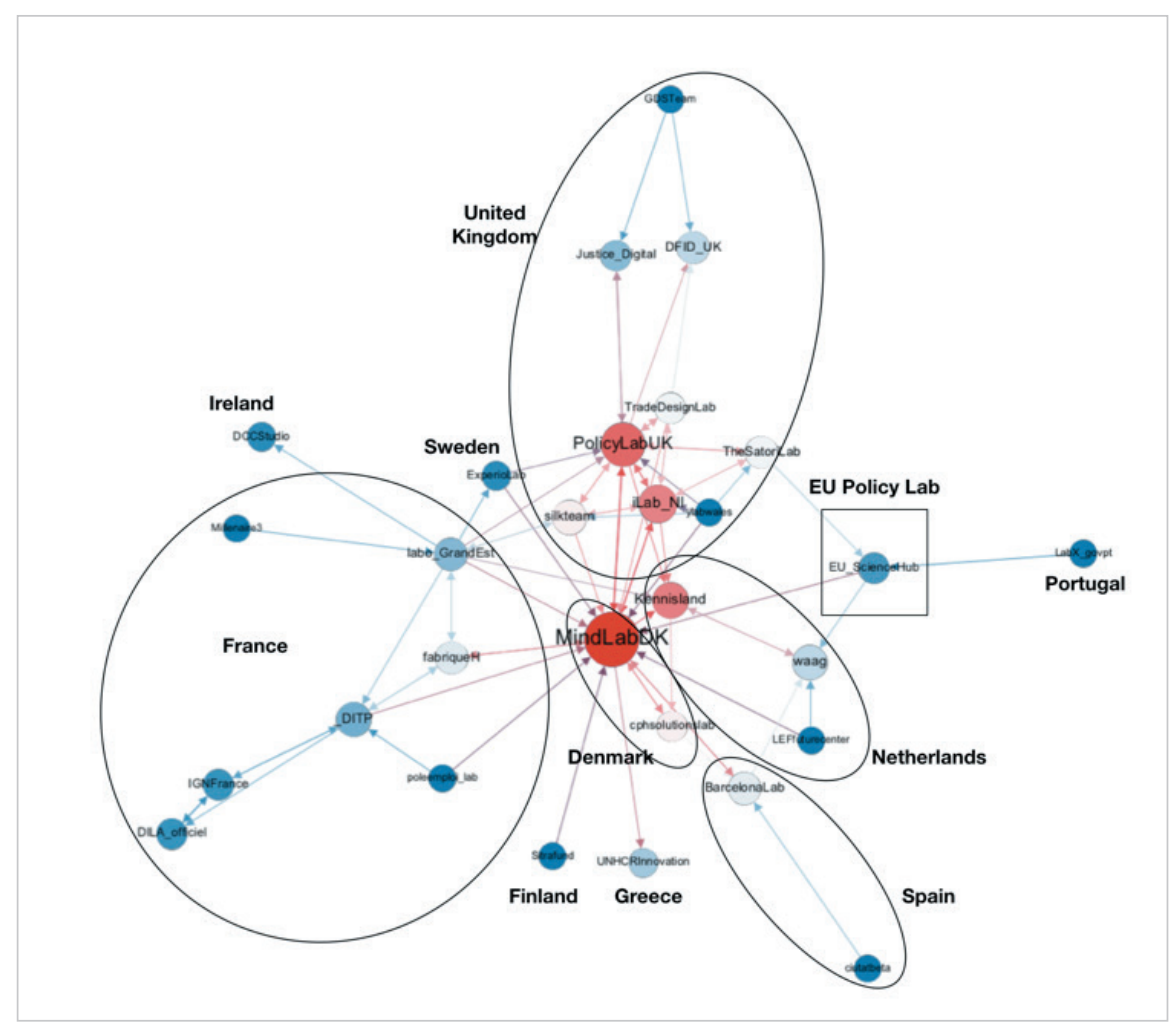

Figure 1. Network of connections between European policy labs 
On the left, a second cluster consists of the 7 French labs. Unlike the British labs, they do not occupy outstanding positions among the European labs on the basis of their centrality. The language variable is the key when assessing the position and scope of lab communications. For example, no French lab is followed by British labs, whereas the opposite is not the case. The labo_GrandEst lab connects these two clusters by linking directly to silkteam and PolicyLabUK and indirectly to the Swedish ExperioLab, which also tweets in English.

Our study draws a map of connections between the 42 laboratories with a presence on Twitter, showing the existence of a territorial imbalance in the identification of these initiatives, with a high number of British (14) and French (8) laboratories

Both clusters have strong connections with MindLabDK - a Danish laboratory created in 2011 by several government ministries - which occupies the position of greatest centrality. It has a website in English and publishes approximately $50 \%$ of its tweets in English.

http://mind-lab.dk/en

Also noteworthy is its high number of retweets with respect to total tweets (47.25\%). In June 2018, this laboratory announced the cessation of its activities at the end of the year. Next to MindLabDK we find another Danish lab, cphsolutionslab, and two small clusters corresponding to the Netherlands and Spain, with 3 and 2 labs respectively.

The other organizations on the map present different types of interconnection. Note the case of EU_ScienceHub, the profile that represents the European Union's policy lab: it is only followed by two laboratories in the sample, which suggests a degree of irrelevance in the global panorama that we have analyzed. We should consider the fact that this profile, although linked to the EU Policy Lab website, belongs to the European Commission Joint Research Center's research and knowledge service.

https://blogs.ec.europa.eu/eupolicylab

Table 2 shows the first 10 labs ordered by eigenvector centrality in the network and the indegree, the number of connections they receive; the outdegree, the number of connections they make; and the degree (the sum of indegree and outdegree). As previously stated, the most central actors on the board are MindLabDK and PolicyLabUK. The Dutch lab Kennisland stands out in third place. Among the top 10, we also find one Spanish lab, BarcelonaLab and one French lab, fabriqueH. The European Commission lab, which is ranked 17 out of 29 , has been included in the table to indicate its position relative to the principal laboratories.
Two laboratories that do not currently publish on Twitter appear in Figure 2 as being interconnected with others: DCCStudio and TradeDesignLab (March 2017).

\subsection{Content analysis of tweets}

In our content analysis of policy lab tweets, only publications originally in English have been included. The diversity of languages limits the scope of our results. However, despite this, 20 laboratories in the sample publish at least $50 \%$ of their tweets in English (Table 3). We have decided to include MindLabDK given its importance and the fact that its percentage of English-language tweets (49.63\%) is very close to this limit. We consider our analysis to be representative of the discourse and nature of the policy labs as political institutions.

Table 3 shows, as at April 24, 2018, the data obtained by extracting the approximately 3200 most recent tweets from each account. The percentage of retweets over total tweets allows us to observe the extent to which policy lab published content is original or based on the selection of third-party content.

In this analysis, UNHCRInnovation has been excluded because as a UN agency, its message is not specifically connected to the European level under study. The EU_ScienceHub account linked to the EU Policy Lab has also been excluded because it is not a national lab.

The development of genuine profiles is important for network positioning and for labs to receive social recognition

To determine the most representative terms in our sample's policy lab tweets, we applied the KeyGraph algorithm which takes account of both frequency and co-occurrenceand identified the 150 most relevant terms in the set of English-language tweets (21391). This means that the same

Table 2. Policy labs ordered by eigenvector centrality

\begin{tabular}{|l|l|c|c|c|c|}
\hline Position & \multicolumn{1}{|c|}{ Policy lab } & $\begin{array}{c}\text { Eigenvector } \\
\text { centrality }\end{array}$ & Indegree & Outdegree & Degree \\
\hline 1 & MindLabDK & 1 & 15 & 7 & 22 \\
\hline 2 & PolicyLabUK & 0.830 & 9 & 8 & 17 \\
\hline 3 & Kennisland & 0.752 & 5 & 2 & 7 \\
\hline 4 & iLab_NI & 0.737 & 6 & 6 & 12 \\
\hline 5 & silkteam & 0.431 & 4 & 4 & 8 \\
\hline 6 & cphsolutionslab & 0.429 & 2 & 2 & 4 \\
\hline 7 & TheSatoriLab & 0.380 & 3 & 3 & 6 \\
\hline 8 & TradeDesignLab & 0.378 & 2 & 4 & 6 \\
\hline 9 & BarcelonaLab & 0.353 & 3 & 2 & 5 \\
\hline 10 & fabriqueH & 0.349 & 3 & 3 & 6 \\
\hline
\end{tabular}


Table 3. The main policy labs' publications in English

\begin{tabular}{|c|c|c|c|c|c|c|}
\hline Policy lab & $\begin{array}{l}\text { Original tweets in } \\
\text { English }\end{array}$ & $\begin{array}{l}\text { Total original } \\
\text { tweets }\end{array}$ & Total retweets & $\begin{array}{c}\text { Total tweets + } \\
\text { retweets }\end{array}$ & $\begin{array}{l}\% \text { own tweets in } \\
\text { English over total } \\
\text { of own tweets }\end{array}$ & $\begin{array}{c}\text { \% retweets over } \\
\text { total tweets }\end{array}$ \\
\hline GDSTeam & 2,957 & 2,959 & 271 & 3,230 & 99.93 & 8.39 \\
\hline Bromford & 2,252 & 2,255 & 945 & 3,200 & 99.87 & 29.53 \\
\hline Justice_Digital & 822 & 827 & 1,039 & 1,866 & 99.40 & 55.68 \\
\hline creativescots & 2,003 & 2,018 & 1,229 & 3,247 & 99.26 & 37.85 \\
\hline DFID_UK & 1,824 & 1,840 & 1,400 & 3,240 & 99.13 & 43.21 \\
\hline PolicyLabUK & 823 & 831 & 2,169 & 3,000 & 99.04 & 72.30 \\
\hline DataMillNorth & 1,368 & 1,384 & 1,286 & 2,670 & 98.84 & 48.16 \\
\hline PDR_Online & 377 & 383 & 113 & 496 & 98.43 & 22.78 \\
\hline TradeDesignLab & 350 & 356 & 208 & 564 & 98.31 & 36.88 \\
\hline iLab_NI & 384 & 391 & 454 & 845 & 98.21 & 53.73 \\
\hline TheSatorilab & 1,329 & 1,356 & 1,727 & 3,083 & 98.01 & 56.02 \\
\hline LBofBexley & 2,376 & 2,425 & 818 & 3,243 & 97.98 & 25.22 \\
\hline DCCStudio & 458 & 473 & 343 & 816 & 96.83 & 42.03 \\
\hline ylabwales & 469 & 487 & 284 & 771 & 96.30 & 36.84 \\
\hline CityofOdense & 122 & 132 & 16 & 148 & 92.42 & 10.81 \\
\hline silkteam & 550 & 616 & 481 & 1,097 & 89.29 & 43.85 \\
\hline LabX_govpt & 56 & 69 & 38 & 107 & 81.16 & 35.51 \\
\hline cphsolutionslab & 128 & 207 & 180 & 387 & 61.84 & 46.51 \\
\hline waag & 1,357 & 2,410 & 804 & 3,214 & 56.31 & 25.02 \\
\hline MindLabDK & 271 & 546 & 489 & 1,035 & 49.63 & 47.25 \\
\hline
\end{tabular}

terminological root may appear more than once in various Twitter accounts or various grammar tags. After unifying the roots, the 150 most relevant terms were edited down to a cloud of 92 unique roots (Figure 2). The size of each term in the map corresponds to its total KeyGraph algorithm score, adding together the scores of those terms that are repeated. Color indicates the individual maximum scores for each term, with no aggregation for equivalent roots. Table 4 shows the first 15 terminological roots ordered by total score, which determines size. Frequency indicates the number of times a root appears in different accounts among the 150 most relevant terms extracted from all accounts.

Eight of the first 10 roots correspond to a semantic field that is typical of the concept of the policy lab as an institution; these are: peopl, servic, data, digit, design, govern. Other roots linked to this theme have also been identified: innov, creativ, user, lab, team, idea, polici, communiti, social, public, citizen, chang. These two tweets containing the root govern illustrate its use:

MindLabDK: MindLab's @JesperC_on achieving a cultural change in government at Politics for Tomorrow https://t.co/y6NoBSi41y \#psilabs \#policyinnovation

https://twitter.com/MindLabDK/status/667669082888622080

TradeDesignLab: Are government measures effective in helping small businesses export? | Economia https://t.co/WhTp191JEH https://twitter.com/TradeDesignLab/status/662008525233725440
The most prominent term is thank, which has been classified within a set of terms that denote actions, among which we also find: look, help, follow, save, mention, requir, export, do, check, think, upload, vote, purchas.

In ninth position is festiv, which refers to a set of terms linked to events and actions organized by the labs. Other

Table 4. First 15 terminological roots by total score

\begin{tabular}{|l|l|c|c|c|}
\hline & $\begin{array}{c}\text { Terminologi- } \\
\text { cal root }\end{array}$ & Total score & $\begin{array}{c}\text { Maximum } \\
\text { score }\end{array}$ & Frequency \\
\hline 1 & thank & 1,740 & 705 & 7 \\
\hline 2 & peopl & 1,158 & 717 & 3 \\
\hline 3 & servic & 1,069 & 657 & 5 \\
\hline 4 & data & 1,015 & 800 & 5 \\
\hline 5 & digit & 865 & 620 & 2 \\
\hline 6 & govern & 829 & 732 & 2 \\
\hline 7 & design & 704 & 216 & 7 \\
\hline 8 & creativ & 663 & 663 & 1 \\
\hline 9 & user & 658 & 658 & 1 \\
\hline 10 & festiv & 641 & 624 & 2 \\
\hline 11 & fund & 629 & 629 & 1 \\
\hline 12 & aid & 624 & 624 & 1 \\
\hline 13 & deadlin & 624 & 624 & 1 \\
\hline 14 & scotland & 619 & 619 & 1 \\
\hline 15 & children & 563 & 563 & 1 \\
\hline
\end{tabular}


words within this group would be: deadlin, week, workshop, event, day, time, and agenda.

Other sets of words refer to topics typically addressed by laboratories. Some of them are: borough, fund, aid, children, support, world, custom, free, cultur, justic, technolog, robot, dementia, copyright, smart, solut, busi, futur, local, tool, network , challeng, democraci, polici. For example, we include two tweets that use cultur:

CreativeScots: Scotland is a creative nation connected to the world - inclusive and open, innovative and pioneering, imaginative and inspiring, it is home to some of the brightest creative talent and host to world-class cultural events \#ScotlandlsNow https://t.co/ XamGtAjKKE

https://twitter.com/CreativeScots/status/984065212742594560

TheSatoriLab: Creating a strong 'office' culture for remote workers https://t.co/XIGpHOtisF https://t.co/j8PCuUjL93

https://twitter.com/TheSatoriLab/status/987374086807486464

\section{Discussion and conclusions}

This article focuses on policy labs, relatively recent political institutions that are gaining relevance due to society's demands for innovation, openness and citizen participation at different levels of government (Rodríguez-Bolívar, 2017). We have taken a global approach to the phenomenon of policy labs by taking the European Commission report (Fuller; Lochard, 2016) as a reference. Our study draws a map of connections between the 42 laboratories with a presence on Twitter, showing the existence of a territorial imbalance in the identification of these initiatives, with a high number of British (14) and French (8) laboratories and the far more limited presence of southern, central and eastern European countries. Although these differences could be attributed to the methodology used to identify labs in the report, we believe it appropriate to explore the role that the administrative culture (Dwivedi, 2005) of countries can play in the emergence of these projects, given that there is much literature that links culture with administrative systems (Bonsón et al., 2012; Schwab; Bouckaert; Kuhlmann, 2017).

For example, Rodríguez-Bolívar (2018) points to the existence of five types of system with differentiated but interconnected characteristics:

\footnotetext{
- Anglo-American (Anglo-American type);

- South European (or Continental European Napoleonic type);

- German (or Continental European Federal type);

- Eastern (Central Eastern European type);

- Scandinavian traditions (or Nordic type).
}

In relation to the use of Twitter (sec- tion 4.1), significant differences exist in the volume of published tweets (mean: 5871.97, SD: 9111.34), an indicator of lab activity on the network, which Zarco, Del-Barrio-García and Cordón (2016) link to the traditional communication or persuasion model which focuses on the mass emission of unidirectional messages to persuade interest groups (Petty; Cacioppo, 1986; 2011). If we look at the number of followers (mean: 17,792.07, SD: 49,139.71), we can estimate the popularity of an institution in absolute terms. The follower/friend ratio is an interesting indicator of the degree of influence that any given lab can exercise on Twitter with respect to other accounts. This clearly represents an opening to future research into policy lab influencers.

The most central roles in the network correspond to laboratories with well-developed digital identities and national coverage

In section 4.2, we have described the network of relationships between European policy labs on Twitter. Of the 42 labs in the sample, 13 lack connections with the rest, which is an indicator of the connectivity of the European lab community on Twitter. Those clusters that do appear are based on national and linguistic factors. Note that the most central roles in the network correspond to laboratories with well-developed digital identities (at website level, in terms of social network profiles, and so on) and national coverage. This is the case of MindLabDK (corresponding to the Danish government) and PolicyLabUK (British government), which occupy the first two positions. The European policy lab occupies a peripheral position with few connections to other entities. One possible explanation lies in the fact that its own digital identity is underexposed on social networks, where its reference profile corresponds to the European Commission 
Joint Research Centre. The development of genuine profiles is important for network positioning and for labs to receive social recognition.

A further point of special interest is the fact that the largest cluster, and some of the most central labs in the network, correspond to the United Kingdom which, once Brexit has been completed, will be outside of the EU. This could considerably weaken the scenario for the current set of European institution-based policy labs.

Clusters are based on national and linguistic factors

Our content analysis of Twitter publications (section 4.3) has shed light on the nature of this type of institution. On the one hand, we find that the most frequently-used terms reinforce their purpose, aligning their tweet contents with the labs' theoretical definitions. Laboratories focus on the idea of innovation and service and public policy design, in which the large-scale participation of citizens is a motor for social change. They do this by activating communities and teams and using an experimental, creative approach in which digital technology and data are central elements.

Especially significant is the set of terms describing their main topics of interest. We have identified a plethora of themes including issues such as:

- the challenges of the local, neighborhoods, cities and the world as a whole;

- aid programs and project funding;

- culture as a whole, with a particular interest in free access to culture and problems relating to copyright;

- childhood;

- justice;

- smart technologies and robotics;

- policies (vs the big idea of "politics");

- democracy as a whole;

- business;

- other specific problems, such as dementia.

If we compare these issues with those identified in the $E C$ report, we observe that in general terms they are connected, although there are significant gaps such as: employment and growth, education, transportation and mobility.

The present study addresses an innovative way of participating in political life through innovation and social participation. Communication is critical in this new kind of relationship between public institutions and society. Therefore, content analysis and the visualization of the Twitter network allow us to obtain an overview that goes beyond theoretical approaches.

As previously indicated, limitations derive from the fact that the agents under study have an unequal presence on Twitter. However, those that we could a priori consider to be more prominent are included in the analysis.

The multiplicity of languages used by the labs makes content analysis difficult, which is why we have focused on English-language tweets, although this somewhat limits the scope of our study. However, many of the accounts do choose English as their first or second option language.

Given that most of the entities analyzed have a national (14) and local (10) scope of action, future research could explore whether laboratories whose main language is not English, use it in order to internationalize problems or the results of their activities or to participate in a global conversation.

In future work, we will consider moving forward to develop a more thorough policy lab identification system, which would allow us to update our portrait of EU labs, their objectives, and their impact.

We will seek to adopt a more detailed approach to our linguistic analysis and investigate the use of hashtags - which could help overcome the linguistic limitations. By conducting a co-occurrence analysis of tweets and a longitudinal study of communication on Twitter we would hope to learn much more about the policy labs' activity.

\section{Acknowledgment}

This work has been possible thanks to financial support from "Knowmetrics: knowledge evaluation in digital society", a project funded by scientific research team grants from the BBVA Foundation, 2016.

\section{References}

Almirall, Esteve; Wareham, Jonathan (2008). "Living labs and open innovation: Roles and applicability". The electronic journal for virtual organizations and networks, v. 10, pp. 21-46.

Barzelay, Michael (2001). The new public management: Improving research and policy dialogue. University of California Press. ISBN: 9780520224438

Bastian, Mathieu; Heymann, Sebastien; Jacomy, Mathieu (2009). "Gephi: An open source software for exploring and manipulating networks". In: Third int AAAI Conf on weblogs and social media, pp. 17-18.

https://gephi.org/publications/gephi-bastian-feb09.pdf

Bonacich, Phillip (2010). "Factoring and weighting approaches to status scores and clique identification". The journal of mathematical sociology, v. 2, n. 1, pp. 113-120.

https://doi.org/10.1080/0022250X.1972.9989806

Bonsón, Enrique; Torres, Lourdes; Royo, Sonia; Flores, Francisco (2012). "Local e-government 2.0: Social media and corporate transparency in municipalities". Government information quarterly, v. 29, n. 2, pp. 123-132.

http://www.unapcict.org/ecohub/local-e-government-2.0social-media-and-corporate-transparency-in-municipalities https://doi.org/10.1016/j.giq.2011.10.001

Castells, Manuel (2013). Communication power. Oxford University Press. ISBN: 9780199567041

Cavallini, Simona; Soldi, Rosella; Friedl, Julia; Volpe, Margherita (2016). Using the quadruple helix approach to accelerate the transfer of research and innovation results to regional growth. European Union. Committee of the Regions. ISBN: 9789289508902

https://doi.org/10.2863/408040 
Ceron, Andrea (2017). "Intra-party politics in 140 characters". Party politics, v. 23, n. 1, pp. 7-17.

https://doi.org/10.1177/1354068816654325

Cherepnalkoski, Darko; Karpf, Andreas; Mozetič, Igor; Grčar, Miha (2016). "Cohesion and coalition formation in the European Parliament: Roll-call votes and Twitter activities". PloS one, v. 11, n. 11.

https://doi.org/10.1371/journal.pone.0166586

Chesbrough, Henry-William (2003). Open innovation: The new imperative for creating and profiting from technology. Boston: Harvard Business School Press. ISBN: 9781 578518371

Chesbrough, Henry-William (2006). Open business models: How to thrive in the new innovation landscape. Boston: Harvard Business School Press. ISBN: 9781422104279

Del-Fresno-García, Miguel (2014). “Haciendo visible lo invisible: visualización de la estructura de las relaciones en red en Twitter por medio del análisis de redes sociales". El profesional de la información, v. 23, n. 3, pp. 46-252.

https://doi.org/10.3145/epi.2014.may.04

Dunleavy, Patrick; Margetts, Helen; Bastow, Simon; Tinkler, Jane (2006). "New public management is dead -long live digital-era governance". Journal of public administration research and theory, v. 16, n. 3, pp. 467-494.

https://doi.org/10.1093/jopart/mui057

Dwivedi, Onkar-Prasad (2005). "Administrative culture and values: Approaches". In: Jabbra, Joseph; Dwivedi, Onkar-Prasad. Administrative culture in a global context. Ottawa: Sitter Publications, pp. 19-36.

http://desitterpublications.com/books/images/admin_intro.pdf

European Commission (2009). Living labs for user-driven open innovation: An overview of the living labs methodology, activities and achievements. Brussels: European Commission, Information Society and Media.

http://www.eurosportello.eu/sites/default/files/Living\%20 Lab\%20brochure_jan09_en_0.pdf

European Commission (2014). Social innovation: A decade of changes. Luxembourg: Publications Office of the European Union. ISBN: 9788279394171

https://doi.org/10.2796/27492

Fuller, Matt; Lochard, Anna (2016). Public policy labs in European Union member states. Publications Office of the European Union. ISBN: 9789279608940

https://ec.europa.eu/jrc/en/publication/public-policy-labseuropean-union-member-states

Golbeck, Jennifer; Hansen, Derek (2011). "Computing political preference among Twitter followers". In: Procs of the SIGCHI conf on human factors in computing systems, pp. 1105-1108. ACM. ISBN: 9781450302289 http://www.cs.umd.edu/hcil/trs/2010-20/2010-20.pdf

Lathrop, Daniel; Ruma, Laurel (2010). Open government: Collaboration, transparency, and participation in practice. O’Reilly Media, Inc. ISBN: 9780596804350

Lewis, Ted G. (2008). Network science: Theory and applications. John Wiley \& Sons. ISBN: 9780470331880
McCombs, Maxwell (1996). "Influencia de las noticias en nuestras imágenes del mundo". En: Bryant, Jennings; Zillmann, Dolf. Los efectos de los medios de comunicación: investigaciones y teorías. Barcelona: Paidós, pp. 13-34. ISBN: $844930296 \mathrm{X}$

Martínez-Rolán, Xabier; Piñeiro-Otero, Teresa (2017). "Lazos invisibles de la comunicación política. Comunidades de partidos políticos en Twitter en unas elecciones municipales". El profesional de la información, v. 26, n. 5, pp. 859-870.

https://doi.org/10.3145/epi.2017.sep.08

Myers, Seth A.; Sharma, Aneesh; Gupta, Pankaj; Lin, Jimmy (2014). "Information network or social network?: The structure of the Twitter follow graph". In: Procs of the $23^{\text {rd }}$ intl conf on world wide web, ACM, pp. 493-498. https://doi.org/10.1145/2567948.2576939

Ohsawa, Yukio; Benson, Nels E.; Yachida, Masahiko (1998). "KeyGraph: Automatic indexing by co-occurrence graph based on building construction metaphor". En: IEEE Intl forum on research and technology advances in digital libraries. ADL 98, pp. 12-18.

http://sclab.yonsei.ac.kr/courses/06mobile/4-1.pdf https://doi.org/10.1109/ADL.1998.670375

Petty, Richard E.; Cacioppo, John T. (1986). "The elaboration likelihood model of persuasion". In: Petty, Richard E.; Cacioppo, John T. Communication and persuasion: Central and peripheral routes to attitude change. New York: Springer, pp. 1-24. ISBN: 9781461293781

https://doi.org/10.1007/978-1-4612-4964-1_1

Petty, Richard E.; Cacioppo, John T. (2011). Communication and persuasion: Central and peripheral routes to attitude change. New York: Springer. ISBN: 9781461293781

Priem, Jason; Hemminger, Bradely H. (2010). "Scientometrics 2.0: New metrics of scholarly impact on the social Web". First Monday, v. 15, n. 7

https://doi.org/10.5210/fm.v15i7.2874

Robinson-García, Nicolás; Costas, Rodrigo; Isett, Kimberley; Melkers, Julia; Hicks, Diana (2017). "The unbearable emptiness of tweeting-About journal articles". PloS one, v. 12, n. 8

https://doi.org/10.1371/journal.pone.0183551

Rodríguez-Bolívar, Manuel-Pedro (2017). "Policy makers' perceptions on the transformational effect of Web 2.0 technologies on public services delivery". Electronic commerce research, v. 17, n. 2, pp. 1-28.

https://doi.org/10.1007/s10660-015-9196-1

Rodríguez-Bolívar, Manuel-Pedro (2018). "Creative citizenship: The new wave for collaborative environments in smart cities". Academia revista latinoamericana de administración, v. 31, n. 1, pp. 277-302.

https://doi.org/10.1108/ARLA-04-2017-0133

Romero-Frías, Esteban; Robinson-García, Nicolás (2017). "Laboratorios sociales en universidades: innovación e impacto en Medialab UGR". Comunicar, v. 25, n. 51, pp. 29-38. https://doi.org/10.3916/C51-2017-03 
Romero-Frías, Esteban; Vaughan, Liwen (2010). “European political trends viewed through patterns of Web linking". Journal of the Association for Information Science and Technology, v. 61, n. 10, pp. 2109-2121. https://doi.org/10.1002/asi.21375

Romero-Frías, Esteban; Vaughan, Liwen (2012). “Exploring the relationships between media and political parties through web hyperlink analysis: The case of Spain". Journal of the Association for Information Science and Technology, v. 63, n. 5, pp. 967-976.

https://doi.org/10.1002/asi.22625

Schwab, Christian; Bouckaert, Geert; Kuhlmann, Sabine (2017). "Autonomy, performance, participation: Lessons from the comparative study of local public sector reforms". In: Schwab, Christian; Bouckaert, Geert; Kuhlmann, Sabine. The future of local government in Europe. Nomos Verlagsgesellschaft mbH \& Co. KG, pp. 11-22.

Sugimoto, Cassidy R.; Haustein, Stefanie; Ke, Qing; Larivière, Vincent (2016). "Social media metrics as indicators of broader impact". En: OECD Blue sky III Forum on science and innovation indicators, pp. 19-21.

https://bit.ly/2U12Kyx

Torres-Salinas, Daniel; Cabezas-Clavijo, Álvaro; Jiménez-Contreras, Evaristo (2013). "Altmetrics: nuevos indicadores para la comunicación científica en la Web 2.0". Comu- nicar, v. 21, n. 41, pp. 53-60.

https://doi.org/10.3916/C41-2013-05

Torres-Salinas, Daniel; Castillo-Valdivieso, Pedro-Ángel; Pérez-Luque, Álvaro; Romero-Frías, Esteban (2018). "Altmétricas a nivel institucional: visibilidad en la Web de la producción científica de las universidades españolas a partir de Altmetric. com". El profesional de la información, v. 27, n. 3, pp. 27-36. https://doi.org/10.3145/epi.2018.may.03

Weaver, Iain S.; Williams, Hywel; Cioroianu, Iulia; Williams, Matthew; Coan, Travis; Banducci, Susan (2018). "Dynamic social media affiliations among UK politicians". Social networks, v. 54, pp. 132-144.

https://doi.org/10.1016/j.socnet.2018.01.008

Wilsdon, James; Allen, Liz; Belfiore, Eleanora; Campbell, Philip; Curry, Stephen; Hill, Steven; Jones, Richard; Kain, Roger; Kerridge, Simon; Thelwall, Mike; Tinkler, Jane; Viney, Ian; Wouters, Paul; Hill, Jude; Johnson, Ben (2015). The metric tide: Report of the independent review of the role of metrics in research assessment and management. https://dx.doi.org/10.13140/RG.2.1.4929.1363

Zarco, Carmen; Del-Barrio-García, Salvador; Cordón, Óscar (2016). "Propuesta de rankings de universidades españolas en redes sociales". El profesional de la información, v. 25, n. 4, pp. 684-698.

https://doi.org/10.3145/epi.2016.jul.18

Annex 1. Description of the policy labs Twitter profiles

\begin{tabular}{|c|c|c|c|c|c|c|}
\hline Policy Lab [Twitter user] & Country & $\begin{array}{c}\text { Data } \\
\text { creation }\end{array}$ & Tweets & Followers & Friends & $\begin{array}{l}\text { Followers/ } \\
\text { friends ratio }\end{array}$ \\
\hline $\begin{array}{l}\text { Barcelona Urban Lab } \\
\text { [BarcelonaLab] }\end{array}$ & Spain & 2013 & 49,939 & 3,154 & 357 & 8.83 \\
\hline $\begin{array}{l}\text { Bexley Innovation Lab } \\
\text { [LBofBexley] }\end{array}$ & United Kingdom & 2009 & 15,946 & 6,438 & 759 & 8.48 \\
\hline $\begin{array}{l}\text { Bromford Lab, Wolverhampton } \\
\text { [Bromford] }\end{array}$ & United Kingdom & 2011 & 12,990 & 5,380 & 852 & 6.31 \\
\hline $\begin{array}{l}\text { City Intelligence Innovation Lab } \\
\text { [DataMillNorth] }\end{array}$ & United Kingdom & 2013 & 2,631 & 3,258 & 1,080 & 3.02 \\
\hline $\begin{array}{l}\text { City of Odense } \\
\text { [CityofOdense] }\end{array}$ & Denmark & 2016 & 148 & 393 & 256 & 1.54 \\
\hline $\begin{array}{l}\text { City of Roskilde } \\
\text { [roskildekommune] }\end{array}$ & Denmark & 2009 & 1,544 & 2,189 & 147 & 14.89 \\
\hline $\begin{array}{l}\text { Ciutat Beta } \\
\text { [CiutatBeta] }\end{array}$ & Spain & 2012 & 1,425 & 794 & 655 & 1.21 \\
\hline $\begin{array}{l}\text { Co Battipaglia } \\
\text { [CoBattipaglia] }\end{array}$ & Italy & 2015 & 31 & 36 & 49 & 0.73 \\
\hline $\begin{array}{l}\text { Co Mantova } \\
\text { [CoMantova] }\end{array}$ & Italy & 2014 & 77 & 63 & 16 & 3.94 \\
\hline $\begin{array}{l}\text { Copenhagen Solutions Lab } \\
\text { [cphsolutionslab] }\end{array}$ & Denmark & 2014 & 383 & 1,032 & 705 & 1.46 \\
\hline DfiD Innovation Hub (London) [DFID_UK] & United Kingdom & 2009 & 20,539 & 293,843 & 2,202 & 133.44 \\
\hline $\begin{array}{l}\text { Direction de la prospective et du dialogue } \\
\text { public } \\
\text { [millenaire3] }\end{array}$ & France & 2010 & 14,672 & 6,040 & 1,953 & 3.09 \\
\hline $\begin{array}{l}\text { EU Policy Lab } \\
\text { [EU_ScienceHub] }\end{array}$ & European Union & 2014 & 12,297 & 19,006 & 4,157 & 4.57 \\
\hline $\begin{array}{l}\text { Experio Lab (Karlstad) } \\
\text { [ExperioLab] }\end{array}$ & Sweden & 2014 & 301 & 512 & 307 & 1.67 \\
\hline
\end{tabular}




\begin{tabular}{|c|c|c|c|c|c|c|}
\hline $\begin{array}{l}\text { Fabrique de l'Hospitalité (Strasbourg) } \\
\text { [fabriqueH] }\end{array}$ & France & 2011 & 681 & 623 & 326 & 1.91 \\
\hline $\begin{array}{l}\text { Futurs Publics (Paris) } \\
\text { [DITP] }\end{array}$ & France & 2010 & 3,887 & 19,232 & 751 & 25.61 \\
\hline Government Digital Services [gdsteam] & United Kingdom & 2011 & 6,227 & 116,104 & 1,178 & 98.56 \\
\hline $\begin{array}{l}\text { IGN Fab (Saint Mandé) } \\
\text { [IGNFrance] }\end{array}$ & France & 2009 & 5,652 & 8,299 & 427 & 19.44 \\
\hline $\begin{array}{l}\text { Kennisland } \\
{[\text { Kennisland] }}\end{array}$ & Netherlands & 2009 & 4,034 & 4,245 & 497 & 8.54 \\
\hline $\begin{array}{l}\text { Lab Pôle Emploi (Paris) } \\
\text { [poleemploi_LAB] }\end{array}$ & France & 2016 & 2,933 & 5,990 & 740 & 8.09 \\
\hline $\begin{array}{l}\text { Lab06, Nice } \\
\text { [AlpesMaritimes] }\end{array}$ & France & 2012 & 8,426 & 48,881 & 734 & 66.60 \\
\hline $\begin{array}{l}\text { LaboDemo (Madrid) } \\
\text { [labo_demo] }\end{array}$ & Spain & 2013 & 1,836 & 825 & 257 & 3.21 \\
\hline $\begin{array}{l}\text { LabX, Lisbon } \\
\text { [LabX_govpt] }\end{array}$ & Portugal & 2017 & 106 & 149 & 24 & 6.21 \\
\hline $\begin{array}{l}\text { Le LABO d'innovation publique } \\
\text { [labo_GrandEst] }\end{array}$ & France & 2015 & 426 & 641 & 774 & 0.83 \\
\hline $\begin{array}{l}\text { LEF Future Centre } \\
\text { [LEFfuturecenter] }\end{array}$ & Netherlands & 2010 & 1,271 & 1,325 & 1,827 & 0.73 \\
\hline $\begin{array}{l}\text { Mindlab (Copenhagen) } \\
{[\text { MindLabDK] }}\end{array}$ & Denmark & 2011 & 1,033 & 6,830 & 1,086 & 6.29 \\
\hline $\begin{array}{l}\text { MoJ Innovation Team } \\
\text { [Justice_Digital] }\end{array}$ & United Kingdom & 2013 & 1,845 & 6,271 & 1,190 & 5.27 \\
\hline $\begin{array}{l}\text { Open Law Lab } \\
\text { [DILA_officiel] }\end{array}$ & France & 2011 & 11,995 & 16,272 & 372 & 43.74 \\
\hline $\begin{array}{l}\text { PDR User Lab } \\
{\left[P D R \_ \text {online }\right]}\end{array}$ & United Kingdom & 2010 & 494 & 707 & 234 & 3.02 \\
\hline $\begin{array}{l}\text { Satori Lab (Cardiff) } \\
\text { [TheSatoriLab] }\end{array}$ & United Kingdom & 2013 & 3,034 & 1,766 & 2,152 & 0.82 \\
\hline $\begin{array}{l}\text { Scottish Govt Creativity Team (Edinburgh) } \\
\text { [CreativeScots] }\end{array}$ & United Kingdom & 2009 & 15,642 & 83,433 & 4,803 & 17.37 \\
\hline $\begin{array}{l}\text { SILK (Maidstone) } \\
\text { [silkteam] }\end{array}$ & United Kingdom & 2013 & 1,101 & 816 & 1,196 & 0.68 \\
\hline $\begin{array}{l}\text { Sitra } \\
\text { [SitraFund] }\end{array}$ & Finland & 2009 & 19,931 & 31,740 & 1,816 & 17.48 \\
\hline $\begin{array}{l}\text { Sundhedsinnovation sjælland (Roskilde) } \\
\text { [PFI_regsj] }\end{array}$ & Denmark & 2014 & 260 & 1,094 & 590 & 1.85 \\
\hline The Innovation Lab (Belfast) [iLab_NI] & United Kingdom & 2015 & 831 & 1,197 & 619 & 1.93 \\
\hline $\begin{array}{l}\text { The Studio } \\
\text { [DCCStudio] }\end{array}$ & Ireland & 2011 & 816 & 583 & 334 & 1.75 \\
\hline $\begin{array}{l}\text { Trafiklab (Stockholm) } \\
\text { [trafiklab] }\end{array}$ & Sweden & 2011 & 484 & 423 & 195 & 2.17 \\
\hline $\begin{array}{l}\text { UK Policy Lab (London) } \\
\text { [PolicyLabUK] }\end{array}$ & United Kingdom & 2014 & 2,979 & 8,504 & 618 & 13.76 \\
\hline $\begin{array}{l}\text { UKTI Ideas Lab (London) } \\
\text { [TradeDesignLab] }\end{array}$ & United Kingdom & 2014 & 564 & 1,357 & 765 & 1.77 \\
\hline $\begin{array}{l}\text { UNHCR Better Shelter Unit (Refugee } \\
\text { Housing Unit) } \\
\text { [UNHCRInnovation] }\end{array}$ & Greece & 2012 & 8,114 & 21,897 & 1,967 & 11.13 \\
\hline $\begin{array}{l}\text { Waag Society } \\
{[\text { waag] }}\end{array}$ & Netherlands & 2009 & 8,333 & 14,550 & 605 & 24.05 \\
\hline $\begin{array}{l}\text { YLabWales } \\
\text { [YLabWales] }\end{array}$ & United Kingdom & 2015 & 765 & 1,375 & 1,248 & 1.10 \\
\hline
\end{tabular}

